Saint Louis University School of Law

Scholarship Commons

All Faculty Scholarship

2010

\title{
In Forma Pauperis, Sec. 514.040: A Practical User's Guide for Attorneys
}

Christine E. Rollins

Saint Louis University School of Law

Follow this and additional works at: https://scholarship.law.slu.edu/faculty

Part of the Legal Education Commons

Recommended Citation

Rollins, Christine, In Forma Pauperis, Sec. 514.040: A Practical User's Guide for Attorneys (January 22, 2010).

This Working Paper is brought to you for free and open access by Scholarship Commons. It has been accepted for inclusion in All Faculty Scholarship

by an authorized administrator of Scholarship Commons. For more information, please contact erika.cohn@slu.edu, ingah.daviscrawford@slu.edu. 
S A I N T L O U I S

$\begin{array}{llllllllll}U & N & \text { I } & V & E & R & S & \text { I } & T & Y\end{array}$

SCHOOL OF LAW

\section{SAINT LOUIS UNIVERSITY SCHOOL OF LAW Legal Studies Research Paper Series}

No. $2010-01$

In forma pauperis, Section 514.040: A Practical User's Guide for Attorneys

Christine E. Rollins

Saint Louis University School of Law

Working Paper

2010

This paper can be downloaded without charge from the Social Science Research Network electronic library at: http://ssrn.com/abstract $=1540612$ 


\section{In forma pauperis, Sec. 514.040: A Practical User's Guide for Attorneys.} Christine E. Rollins ${ }^{1}$

The costs of litigation continue to rise each year as do the number of persons in our community who are minimally, under and unemployed. This combination has put up additional roadblocks for many who seek redress through our court systems. In this time of economic upheaval, it is good to reacquaint ourselves with available resources for our clients who meet the statutory definition of "indigency" as defined in Section 514.040. ${ }^{2}$ Once qualified under Sec. 514.040, parties can have various litigation costs waived.

Section 514.040 sets up a two-stage inquiry for those requesting to proceed in forma pauperis. First, the court must determine the party's eligibility for the benefits of the statute based upon whether the party is unable to pay for the costs and expenses of litigation. ${ }^{3}$ During the second stage, once the party is deemed eligible, the court considers factors which have a bearing on whether the party ought to be allowed to proceed as a poor person. ${ }^{4}$

The first stage of inquiry carries with it the duty of the court to entertain an application from a party to proceed in forma pauperis. ${ }^{5}$ The application has no set form or pleading requirements. Local courts may have preprinted forms to use, others do not. However, most filings include a motion to proceed in forma pauperis and an affidavit(s) in support of the motion. ${ }^{6}$ A party should make a showing of the financial income/expenses of the party to meet the reviewing standards of the courts. ${ }^{7}$

The standard of proof is whether the court has "satisfied" itself that the party is eligible to proceed as a poor person. ${ }^{8}$ It is anticipated that most cases will be determined based on the motion filed and accompanying affidavits. ${ }^{9}$ For some cases an evidentiary hearing to determine the party's status may be required. ${ }^{10}$ This is so because the Statute does not grant the court the authority to permit just anyone to sue as a poor person. ${ }^{11}$

For the second stage, the standard of proof is more policy based. Courts generally follow the policy that "the privilege to litigate as a poor person should be restricted to those who are clearly entitled to it so that the statute will not be abused, but a liberal construction should be applied in close or questionable cases to make sure that a litigant who is

\footnotetext{
${ }^{1}$ Christine E. Rollins received her law degree from Saint Louis University School of Law. Currently, she is an Associate Professor and the Director of the Legal Research and Writing Department at Saint Louis University. She spent five years as an attorney at Legal Services of Eastern Missouri.

${ }^{2}$ All Statutory references are to RSMO 2006.

${ }^{3}$ Coats v. Lewis, 689 S.W.2d 800, 804 (Mo. App. W.D. 1985).

${ }^{4}$ Id.

${ }^{5}$ Id. at 805, citing Steffler v. U.S., 319 U.S. 38, 40 (1943).

${ }^{6}$ Coats, 689 S.W.2d at 806.

${ }^{7}$ For adequacy of pleadings see Coats.

${ }^{8}$ Coats, 689 S.W.2d at 806.

${ }^{9}$ Id.

${ }^{10} \mathrm{ld}$.

"Id. at 804.
} 
entitled to such privilege is not deprived of it." 12 The court examines the "petition to see if it is patently and irreparably frivolous or malicious on its face so that as pleaded [movant] could prove no set of facts entitling him to relief."13

Once the client has been determined to be indigent and the cause of action is sufficient to proceed, Sec. 514.040.1 allows for the person to have "all necessary process and proceedings as in other cases, without fees, tax or charge as the court determines the person cannot pay." While the legislature did not enumerate specific items within the Statute, Missouri law does require that "words and phrases [of statutes] be taken in their plain or ordinary and usual sense."14 In addition, the Appellate District Courts of Missouri have provided litigants and attorneys guidance over the past two decades.

\section{Filing Fees:}

In Trice v. State,${ }^{15}$ the state contended that the party's motion was not timely filed because instead of paying the appropriate fee, the party filed an in forma pauperis affidavit. Citing Coats v. Lewis, the Western District held that courts should allow alleged indigent parties to file petitions along with the appropriate in forma pauperis filings instead of fees. ${ }^{16}$ The petitions are deemed "filed" as jurisdiction does not depend upon payment of fees. The in forma pauperis motion is subject to the court's determination of indigency. Filing fees are necessary "costs" of litigation defined in Sec. 514.040 .

\section{Service Costs:}

Section 514.040.1 states that once a party's in forma pauperis motion has been granted they "shall have all necessary process" afforded to them. Courts have traditionally found service through law enforcement is covered by the meaning of the Statute. ${ }^{17}$ If personal service cannot be perfected the next step, in most cases, is service by publication. ${ }^{18}$ The Court of Appeals, in State ex. rel. Taylor v. Clymer, was faced with the question as to whether service by publication fell within the "necessary process and proceedings" meaning of Sec 514.040. ${ }^{19}$ "Respondents contend[ed] that relators [had] received complete access to the court because they [had] been allowed to file their actions as poor persons" and did not have to pay the filing fee. ${ }^{20}$ In addition, respondents argued that the "State [was] not further obligated to expand relators' rights by affording them services of process by publication without costs." 21 The court disagreed. The court determined that

\footnotetext{
${ }^{12}$ In re Adoption of J.P.S. v. J.E.S., 876 S.W.2d 762, 769 (Mo. App. S.D. 1994).

${ }^{13}$ Coats, 689 S.W.2d at 806.

${ }^{14} \mathrm{Sec} .1 .090$

${ }^{15} 792$ S.W.2d 672, 673-74 (Mo. App. W.D. 1990).

${ }^{16}$ Id.

${ }^{17}$ State ex rel. Scott v. Roper, 688 S.W.2d 757, 759 (Mo. banc 1985). Sec 514.040 requires that all officers of the court serve without fee beyond their annual salary which includes law enforcement.

${ }^{18}$ Section 506.160 provides that "Service by mail or publication shall be allowed in all cases affecting a fund, will, trust estate, specific property, or any interest therein, or any res or status within the jurisdiction of the court, or in any special proceedings in which notice by mail or by publication is authorized, including but not limited to actions to quiet title and actions to ascertain and determine title to real estate.

${ }^{19} 503$ S.W.2d 53, 54 (Mo. App. 1973).

${ }^{20} \mathrm{Id}$. at 56.

${ }^{21}$ Id.
} 
"service accomplishes the fact of jurisdiction and not the filing" of the petition. ${ }^{22}$ The court held that service was within the meaning of the necessary process and proceedings language of Sec. 514.040. Since service by publication was required to continue with the cause of action, the court held that "order of publication should be issued without cost to relators under the mandate of our statutes and the policy of this State to provide indigents free access to our courts." 23

\section{Guardian ad litem fees:}

The Missouri Court of Appeals Eastern Division held in 2000 and then reaffirmed in 2009 that guardian ad litem fees were covered by the language of Section 514.040. In State ex rel. Holterman v. Patterson, ${ }^{24}$ the court of appeals was asked to rule on whether guardian ad litem fees fell within Sec. 514.040. In Holterman, Relator was indigent. She could not pay the guardian ad litem fees assessed by the trial court. Relator understood the guardian deserved to be paid for services rendered and therefore filed a motion with the trial court to join the county as a third party and requested that fees be paid out of public funds. ${ }^{25}$ The trial court denied her motion and required Relator to pay one-third of the $\$ 1,000$ fee. Relator filed a Writ with the Eastern District. The Court of Appeals reasoned that since it had been determined that Relator was "unable to pay the costs, fees and expenses necessary to prosecute or defend the action," Sec. 514.040 leaves no discretion for the trial judge to assess the guardian ad litem fees against Relator. ${ }^{26}$ In Bober v. Bober, 2009, The Eastern District affirmed the holding in Holterman stating that guardian ad litem fees are covered under Sec. 514.040 even if the party is determined to be indigent after litigation had commenced. ${ }^{27}$

\section{Attorney fees - opposing counsel:}

In Versey $v$. Jirak, mother was first represented by private counsel and then when her funds were depleted she was represented by a legal aid attorney. ${ }^{28}$ At the end of trial mother was ordered to pay $\$ 1000.00$ of opposing counsel's attorney fees and was held jointly and severally liable for the guardian ad litem fees. On appeal, Father argued that during the first part of the litigation mother was represented by private counsel and that although mother claimed her funds were depleted and she was represented by legal aid during the trial, these facts should distinguish the previous holdings regarding Sec.

$514.040 .^{29}$ The Eastern District disagreed. They held that once a party was determined to be indigent, all costs and fees (guardian ad litem and attorney fees) are waived for the indigent party. ${ }^{30}$

\footnotetext{
${ }^{22} I d$.

${ }^{23}$ Id .

${ }^{24} 24$ S.W.3d 784 (Mo. App. E.D. 2000).

${ }^{25} \mathrm{Id}$. at 785 .

${ }^{26} I d$.

${ }^{27} 277$ S.W.3d 294, 297 (Mo. App. E.D. 2009).

${ }^{28} 219$ S.W.3d 774, 776 (Mo. App. E.D. 2009).

${ }^{29}$ Id. at 777 .

${ }^{30}$ Id.
} 
Trial transcripts and legal files - on appeal:

Pursuant to two writs of mandamus, State ex. rel. Wecker v. Ohmer, May 6 (Wecker I $)^{31}$ and State ex. rel Wecker v. Ohmer, June 10 (Wecker $I)^{32}$ the Eastern District court of appeals considered whether relator was entitled to obtain a transcript of her termination of parental rights trial and whether she should be required to pay to have her legal file prepared. Mother had filed a timely appeal from the trial court's determination that she lost rights to her children. Both the transcript and legal file are required on appeal. Mother requested to proceed with the appeal as a poor person under Sec. 514.040.

In Wecker I, mother filed a request for her trial transcript which the trial court denied. ${ }^{33}$ Arguing against the Writ, Respondent opined that since Relator had been represented by private counsel during the trial, she was not allowed to request the trial transcript as a poor person. Trial counsel filed an affidavit with the appellate court stating that he had taken on the trial representation pro bono. ${ }^{34}$ Likewise, trial counsel was assisting legal aid in prosecution of the appeal pro bono. The Eastern District determined that since a copy of the trial transcript was necessary to prosecute the appeal and Relator was determined to be eligible under Sec. 514.040, the costs associated with the production of the trial transcript should be paid out of public funds. Closely following the decision in Wecker I, the Eastern District determined in Wecker II that costs associated with producing the legal file were also covered under Sec. 514.040. ${ }^{35}$

\section{Victims of Domestic Assault - Sec. 488.610:}

Victims of domestic assault, stalking or domestic violence have additional areas that fees and costs are statutorily waived. Section 488.610 provides that victims of assault, stalking and domestic violence may not be charged for fees associated with the filing of criminal charges against the offender, or the costs associated with the filing, issuance, registration or service of a warrant, protection order, petition for protection order or witness subpoena. ${ }^{36}$

\section{Additional opportunities - 514.040.3:}

The most recent amendment to Sec. 514.040 became effective on August 28, 1999, when subsection 3 was added. ${ }^{37}$ It allows for a legal aid society, a legal services or other nonprofit organization, to certify that a client is indigent within the meaning of Sec. 514.040.

\footnotetext{
${ }^{31} 105$ S.W.3d 511 (Mo. App. E.D. 2003).

${ }^{32} 108$ S.W.3d 129 (Mo. App. E.D. 2003).

${ }^{33} 105$ S.W.3d at 512-13.

${ }^{34} I$. at 513 .

${ }^{35} 108$ S.W.3d at 129.

${ }^{36}$ Sec. 488.610 .

${ }^{37} \mathrm{Sec}$. 514.040.3. Where a party is represented in a civil action by a legal aid society or a legal services or other nonprofit organization funded in whole or substantial part by moneys appropriated by the general assembly of the state of Missouri, which has as its primary purpose the furnishing of legal services to indigent persons, or by private counsel working on behalf of or under the auspices of such society, all costs and expenses related to the prosecution of the suit may be waived without the necessity of a motion and court approval, provided that a determination has been made by such society or organization that such party is unable to pay the costs, fees and expenses necessary to prosecute or defend the action, and that a certification that such determination has been made is filed with the clerk of the court.
} 
The certification lets the court know that an assessment of the party's financial ability has occurred and that the party is unable to bear the costs associated with litigation. According to the Statute, once the certificate has been filed, trial courts have no discretion to "re-determine" the party's eligibility. Therefore, if attorneys contact their local legal services offices and volunteer to take cases, they obtain all the benefits under Sec. 514.040 without having to work through the filings and possible evidentiary hearing otherwise required.

Currently there are four legal aid offices servicing the state: Legal Aid of Western Missouri, located in Kansas City; Legal Services of Southern Missouri, located in Springfield; Legal Services of Eastern Missouri, located in St. Louis; and Mid-Missouri Legal Services Corporation, located in Columbia. Each of these agencies has satellite offices in various communities across the state. Interested attorneys can either call their local office or, alternatively, The Missouri Bar has made it easy to volunteer by providing volunteer information on their web site. The legal services offices screen all cases and then match volunteer attorneys with appropriate clients. 